\title{
Production and Characterization of Barium-Titanate Nanofibers
}

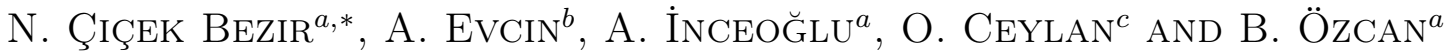

${ }^{a}$ Süleyman Demirel University, Department of Physics, Faculty of Art and Science, Isparta, Turkey

${ }^{b}$ Afyon Kocatepe University, Department of Materials Science and Engineering, Afyonkarahisar, Turkey

${ }^{c}$ Akdeniz University, ElmalıVocational School, Antalya, Turkey

This paper reports production of nanofibers with voltage value of $20 \mathrm{kV}$, different fluid velocities $(0.1 \mathrm{ml} / \mathrm{h}, 0.5 \mathrm{ml} / \mathrm{h})$, different durations $(2 \mathrm{~min}, 5 \mathrm{~min})$, and distance of $7 \mathrm{~cm}$ in the electrospin assembly. The morphology of the produced nanofibers was observed before and after heat treatment by scanning electron microscope. The crystal structure of the nanofibers was examined by X-ray diffraction. In addition, thermal analysis/thermal gravimetric analysis of nanofibers was performed. X-ray diffraction measurements showed that the samples were crystalline in barium titanate. It was observed that the diameters of the nanofibers increased when the flow rate and time increased, while the diameters of the nanofibers decreased when the flow rate and time decreased. Scanning electron microscope images showed how the morphology of the samples changed by heat treatment. As a result, characterization results were found to be consistent with the literature.
\end{abstract}

DOI: 10.12693/APhysPolA.137.542

PACS/topics: barium-titanate, electrospinning, nanofibers, XRD, SEM

\section{Introduction}

Nanotechnology refers to the control and reconstruction of material, which is smaller than $100 \mathrm{~nm}$ or at least one dimension [1]. Therefore, it causes creative changes in human life with new nanotechnological fields for the synthesis of nanomaterials [2,3]. Nanofibers in the group of nanostructured materials have numerous distinguishing features, such as large surface area-to-volume ratios, flexibility of surface functions, and superior mechanical properties [4]. Therefore, nanofibers are efficient nanomaterials. Nanofibers created from various materials such as polymers, carbon, and semiconductors have a comprehensive area of application. Some of these applications are tissue engineering, filter media, nanocomposites reinforcement, and micro/nanoelectromechanical systems [5].

Recently, some researchers have analyzed the features of nanofibers produced by preparing a barium-doped $\mathrm{TiO}_{2}$ solution in their studies [6-8].

In this study, barium titanate nanofibers were prepared by using electrospinning process. Nanofibers were produced with $20 \mathrm{kV}$ voltage value, different fluid velocities $(0.1 \mathrm{ml} / \mathrm{s}, 0.5 \mathrm{ml} / \mathrm{s})$, different durations $(2 \mathrm{~min}$, $5 \mathrm{~min}$ ) and distance of $7 \mathrm{~cm}$. Then, morphology of the produced nanofibers was examined by scanning electron microscope (SEM) before and after heat treatment. The crystal structure of the nanofibers was observed by X-ray diffraction (XRD). Additionally, thermal analysis/thermal gravimetric analysis (DTA/TGA) of nanofibers was performed.

*corresponding author; e-mail: nalancicek@sdu.edu.tr

\section{Materials and method}

The fabrication of the barium-titanate nanofibers was the results of the following steps: polyvinylpyrrolidone (PVP), barium acetate $\left(\mathrm{Ba}\left(\mathrm{C}_{2} \mathrm{H}_{3} \mathrm{O}_{2}\right)_{2}\right)$, titanium isopropoxide $\left(\mathrm{C}_{12} \mathrm{H}_{28} \mathrm{O}_{4} \mathrm{Ti}\right)$, acetic acid $\left(\mathrm{CH}_{3} \mathrm{COOH}\right)$, polyethylene glycol $\left(\mathrm{HO}\left(\mathrm{C}_{2} \mathrm{H}_{4} \mathrm{O}\right)_{n} \mathrm{H}\right)$, ethanol $\left(\mathrm{C}_{2} \mathrm{H}_{5} \mathrm{OH}\right)$, and diethanolamine $\left(\mathrm{C}_{4} \mathrm{H}_{11} \mathrm{NO}_{2}\right)$ were supplied by Merck, Carlo Erba, and Fluka Co.

Firstly, the solution required for electrospinning process was prepared in the experimental part of the study. To obtain the first solution, a solution of $\mathrm{TiO}_{2}$ was prepared first. For this, $2.28 \mathrm{~g}$ titanium isopropoxide was weighed in a beaker, $1.05 \mathrm{~g}$ of diethanolamine were added drop by drop, and they were mixed in magnetic mixer. To this mixed solution $100 \mathrm{ml}$ of ethanol was added and mixing was continued. In addition, $0.8 \mathrm{~g}$ of polyethylene glycol was added to the solution and mixed in a magnetic mixer for $1 \mathrm{~h}$ until the solution was clear.

After this, the solution was taken to a different place, and $2.61 \mathrm{~g}$ of barium acetate was dissolved in $25 \mathrm{ml}$ of acetic acid. This solution was also dissolved in $3 \mathrm{~g}$ of PVP with $30 \mathrm{ml}$ of ethanol after being put in a separate place. In order to produce the nanofibers, $3 \mathrm{ml}$ of the stock $\mathrm{TiO}_{2}$ solution prepared in a separate beaker was taken and $3 \mathrm{ml}$ of barium acetate solution was added on it.

Finally, $14 \mathrm{ml}$ of PVP was added to this solution and mixed in a magnetic mixer for half an hour. To obtain the second solution, primarily $2.84 \mathrm{~g}$ of titanium isopropoxide was dissolved in $10 \mathrm{ml}$ ethanol. Later, $2.55 \mathrm{~g}$ of barium acetate was dissolved in $10 \mathrm{ml}$ of acetic acid in a separate place. Finally, $2 \mathrm{~g}$ of PVP was dissolved in $10 \mathrm{ml}$ of ethanol. In the latest titanium isopropoxide solution, barium acetate solution and $10 \mathrm{ml}$ of PVP solution were added and mixed in the magnetic mixer for another half hour. 


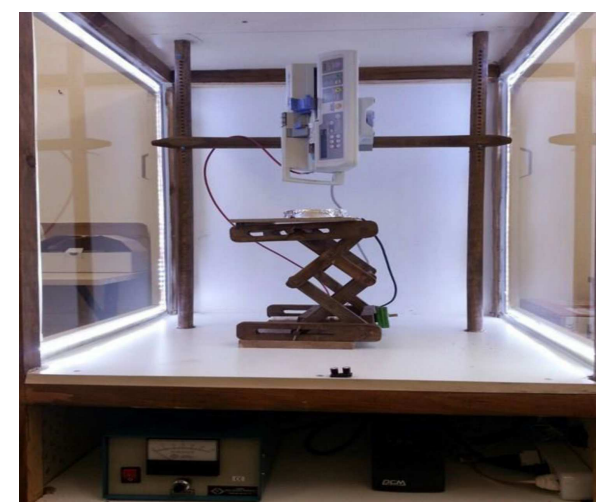

Fig. 1. Home-made electrospinning setup.

All samples have been produced at a constant voltage of $20 \mathrm{kV}$ at constant distance of $7 \mathrm{~cm}$, duration of $2 \mathrm{~min}$ and $5 \mathrm{~min}$, and with a constant rate of $0.1 \mathrm{ml} / \mathrm{s}$ and $0.5 \mathrm{ml} / \mathrm{s}$ by electrospinning device at room temperature.

Nanofibers were produced by means of the home-made electrospinning experimental setup (Fig. 1).

\section{Results and conclusion}

Results of experiments were examined in terms of system parameters (flow rate and applied time) and morphology. Nanofibers were heat treated for $1 \mathrm{~h}$ at $1100^{\circ} \mathrm{C}$. As a result, the amorphous structure has been crystallized by the removal of PVP. The morphological structure of the obtained nanofibers was examined with SEM images and the diameters of the nanofibers were determined. In addition, DTA/TGA and XRD analyses were performed.

The effect of time and flow rates applied to the first solution on nanofibers is seen in Fig. 2. Figure 3 shows DTA/TGA analysis of powders obtained from $\mathrm{BaTiO}_{3}+$ PVP solution.

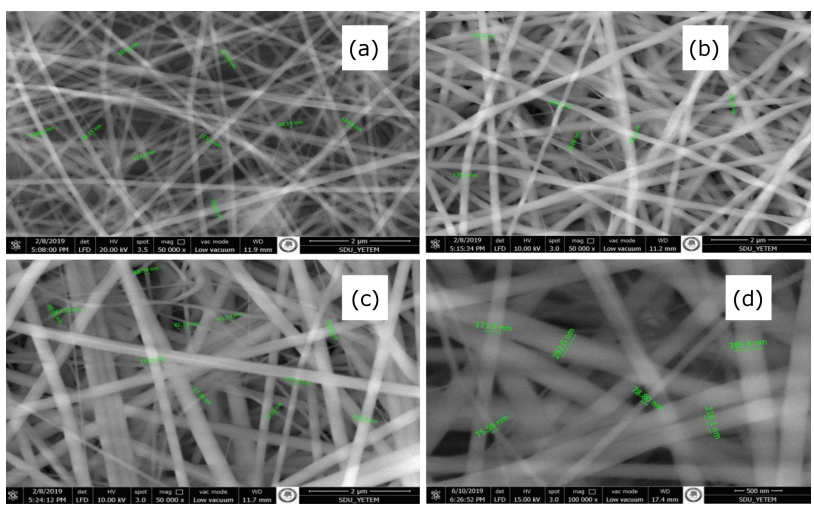

Fig. 2. First solution, diameters of nanofibers produced by pre-heat treatment flow rate of nanofibers at a distance of $7 \mathrm{~cm}$ : (a) $2 \mathrm{~min}, 0.1 \mathrm{ml}$ flow rate, (b) $5 \mathrm{~min}$, $0.1 \mathrm{ml}$ flow rate, (c) $2 \mathrm{~min}, 0.5 \mathrm{ml}$ flow rate, (d) $5 \mathrm{~min}$, $0.5 \mathrm{ml}$ flow rate.

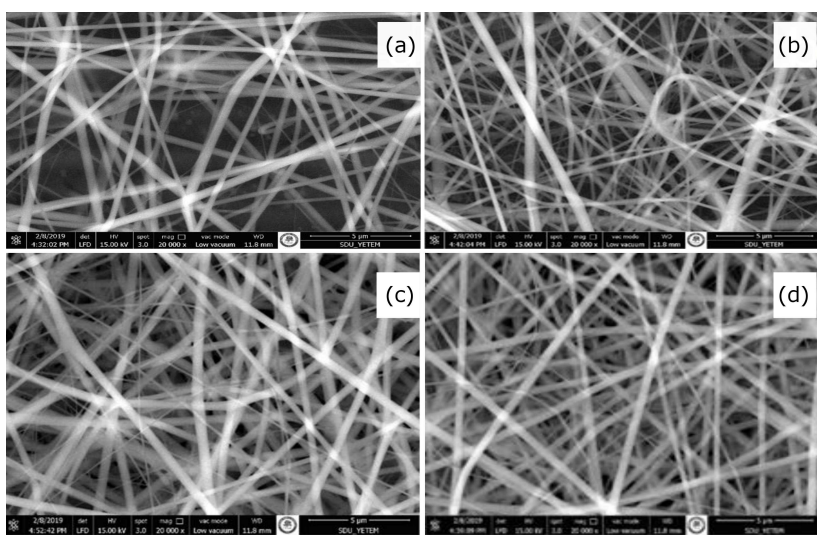

Fig. 3. As in Fig. 2, but for second solution.

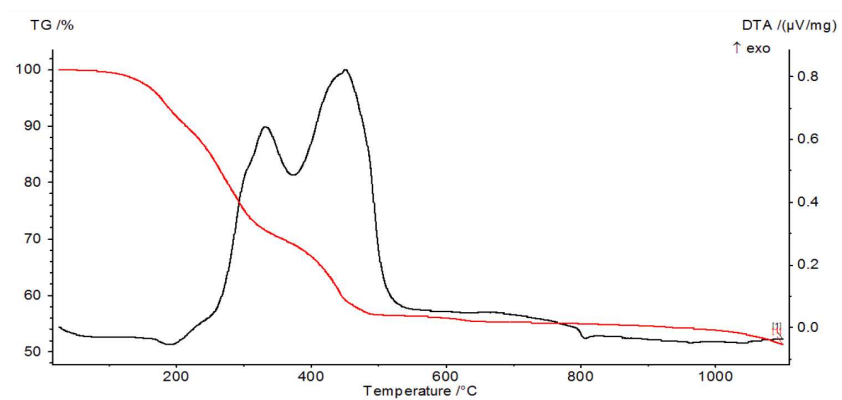

Fig. 4. DTA/TGA analysis of powders obtained from $\mathrm{BaTiO}_{3}+$ PVP solution.

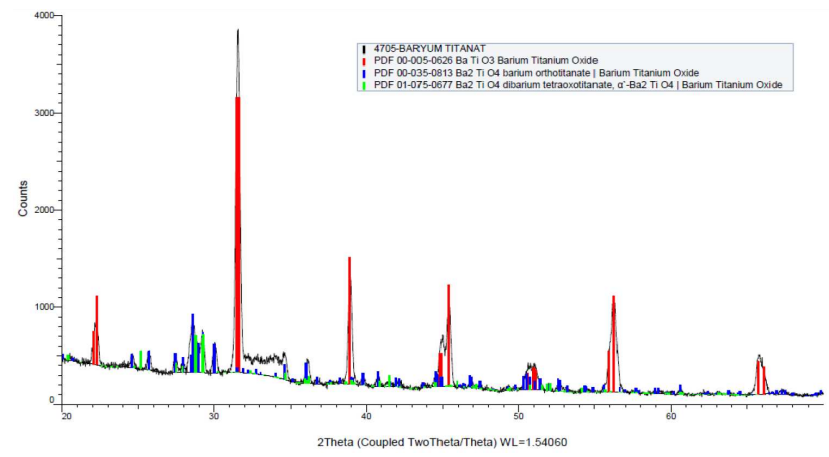

Fig. 5. The XRD graph of $\mathrm{BaTiO}_{3}$ powder.

The effect of time and flow rates applied to the second solution on nanofibers is seen in Fig. 3.

Figure 4 shows two strong peaks in the DTA analysis of $\mathrm{BaTiO}_{3}$ solution. The endothermic peak occurs at $430^{\circ} \mathrm{C}$ and the exothermic peak occurs at $450^{\circ} \mathrm{C}$. Figure 5 shows the XRD graph of $\mathrm{BaTiO}_{3}$ powder.

For the red peaks, barium is orthogonal, while for the green peaks, titanium and barium are tetragonal. The results are in agreement with the literature. Table I shows effect of duration and flow rates on diameters of $\mathrm{BaTiO}_{3}$ nanofibers. 
TABLE I

Effect of duration and flow rates on diameters $d$ of $\mathrm{BaTiO}_{3}$ nanofibers at constant distance of $7 \mathrm{~cm}$ and applied voltage $20 \mathrm{kV}$.

\begin{tabular}{c|c|c|c|c}
\hline \hline $\begin{array}{c}\text { Min. } d \\
{[\mathrm{~nm}]}\end{array}$ & $\begin{array}{c}\text { Max. } d \\
{[\mathrm{~nm}]}\end{array}$ & $\begin{array}{c}\text { Average } d \\
{[\mathrm{~nm}]}\end{array}$ & $\begin{array}{c}\text { Flow rate } \\
{[\mathrm{mL}]}\end{array}$ & $\begin{array}{c}\text { Time } \\
{[\mathrm{min}]}\end{array}$ \\
\hline 38.15 & 153.6 & 95.875 & 0.1 & 2 \\
29.06 & 178.1 & 103.58 & 0.1 & 5 \\
43.50 & 234.3 & 138.9 & 0.5 & 2 \\
75.59 & 292.0 & 183.795 & 0.5 & 5
\end{tabular}

\section{Acknowledgments}

This work was supported by Süleyman Demirel University via Scientific Research Projects 4690-YL1-16.

\section{References}

[1] NSTC, The National Nanotechnology InitiativeStrategic Plan, December 2007, Executive Office of the President of the United States, 2007.

[2] R. Zhang, Y. Zhang, Z.C. Dong, S. Jiang, C. Zhang, L.G. Chen, J.L. Yang, Nature 498, 82 (2013).
[3] S.J. Park, Y.S. Jang, J. Coll. Interface Sci. 261, 238 (2003).

[4] G. Panthi, M. Park, H.Y. Kim, S.J. Park, J. Industr. Eng. Chem. 24, 1 (2015).

[5] E.P.S. Tan, C.T. Lim, Composit. Sci. Technol. 66, 1102 (2006).

[6] Z. Dan, J. Jiang, X. Zhang, J. Qian, Z. Shen, C. Nan, Y. Shen, Ceram. Int. 46, 1119 (2020).

[7] K. Vijayalakshmi, D. Sivaraj, RSC Adv. 6, 9663 (2016).

[8] W. Wang, Y. Ye, J. Feng, M. Chi, J. Guo, Y. Yin, Angew. Chem. Int. Ed. 54, 1321 (2015). 